\title{
Um texto médico em língua portuguesa e grafia hebraica: o Neseçario (Ms. Vat. ebr. 372)
}

\section{A Medical Text in Portuguese Language and Hebrew Script: the Neseçario (Ms. Vat. Ebr. 372)}

\begin{abstract}
Valentina Cantori*
Resumo: Depois de abordar o contexto da península ibérica durante a Idade Média, em que a influência da cultura islâmica se torna determinante para a produção científica coeva e posterior, falarei dos textos românicos em grafia hebraica, que caracterizam a produção manuscrita nos ambientes judaicos dessa época. Neste trabalho apresentarei os primeiros capítulos do Neseçario, um tratado médico-cirúrgico que integra o códice Vat. ebr. 372 ( século XV), redigido em língua portuguesa e cursivo sefardita; falarei também das fontes médicas que contribuíram para sua composição e de suas principais caraterísticas.

Palavras-chave: Manuscritos hebraicos. Língua portuguesa. História da medicina. Península ibérica. Idade Média.

Abstract: After approaching the context of the Iberian peninsula during the Middle Ages, in which the influence of the Islamic culture had been decisive for the scientific production, contemporary and subsequent, I will talk about Romance texts in Hebrew script. These texts distinguish the manuscript production in the Jewish environment of this period. In this work I will present the first chapters of Neseçario, a medical-surgical treatise belonging to the codex Vat. ebr. 372 (XV century). The codex was written in Portuguese language and Sephardic cursive script. I will also talk about the medical sources that contributed to its composition and its main characteristics.
\end{abstract}

Keywords: Hebrew manuscripts. Portuguese language. History of medicine. Iberian peninsula. Middle Ages.

$\mathrm{O}$ reino de al-Andaluz determinou um período de grande efervescência para a região ibérica, que reverberaria também nos séculos posteriores; nessa encruzilhada de línguas, fés e tradições, coexistiam, não sempre de modo pacífico, muçulmanos, judeus e cristãos.

Ao lado do hebraico, língua das Escrituras Sagradas e da tradição textual, os judeus ibéricos conheciam o hispano-românico dos territórios habitados, utilizado na comunicação do dia a dia; do contato entre o hebraico e as variedades hispânicas nasceriam novas formas linguísticas, conservadas também na diáspora. Os judeus provenientes das regiões islâmicas

\footnotetext{
* Valentina Cantori é pós-doutoranda no Departamento de Letras Orientais da Faculdade de Filosofia, Letras e Ciências Humanas da Universidade de São Paulo, doutora em Letras pela Universidade de Macerata e pela Universidade Hebraica de Jerusalém. E-mail: <valentina.cantori@gmail.com>.
} 
conheciam o árabe, fato que lhes permitia o acesso a um patrimônio cultural extremamente vasto, e os tornava ativos no papel da transmissão do saber.

Entre os séculos XI e XII, nos ambientes tanto muçulmanos quanto judaicos se intensificou a produção de textos científicos, filosóficos e teológicos: Ibn Bajja, Averróis, Yehuda Ha-Levi e Maimônides pertencem a esse período. A partir do século XII apareceram as primeiras traduções do árabe para o latim, ${ }^{2}$ e um século mais tarde chegariam as traduções para o castelhano, ${ }^{3}$ veiculando a transmissão do Oriente para o Ocidente de um saber até então desconhecido; os judeus tiveram um papel fundamental nessa atividade, seja como colaboradores nas traduções para o latim, ${ }^{4}$ seja como tradutores para o castelhano. ${ }^{5}$

Nesse contexto multilíngue se desenvolve uma produção textual própria dos ambientes judaicos: a dos textos em língua românica e grafia hebraica. Os autores desses códigos são judeus alfabetizados, que usam a língua românica e a grafia hebraica por uma questão prática: por um lado, o idioma hispano-românico expressa a língua da comunicação corriqueira, por outro, a grafia hebraica é considerada a mais familiar, porque o hebraico é a língua da educação judaica, do texto bíblico e das orações. O conhecimento do hebraico permite a aproximação da vida espiritual e o desenvolvimento do vínculo comunitário, além de ser uma língua de estudo; o uso desse idioma se dá na dimensão escrita, sendo utilizado para redigir comentários, tratados, documentos e outros textos práticos, porém não na fala. Os judeus letrados não desconheciam o latim, língua da cultura europeia e da cristandade, mas, ainda assim, não eram muito inclinados a usá-lo, e quando redigiam um texto em língua latina se utilizavam da grafia hebraica. ${ }^{6}$

É importante ressaltar que os textos em grafia hebraica e em língua não hebraica, mesmo que nos territórios ibéricos de época medieval tenham encontrado um ambiente particularmente fértil e naturalmente predisposto, não são exclusivos dessa região e dessa época: inúmeros são, de fato, os manuscritos medievais de Itália, França e outras regiões mediterrâneas, como

\footnotetext{
2 Textos científicos já haviam sido traduzidos do árabe para o latim por Constantino, o Africano (1020-1087), ativo na península itálica e no norte da África; sua contribuição seria determinante para as práticas da Scuola Medica Salernitana.

${ }^{3}$ As traduções para o castelhano feitas na corte de Alfonso X representam um capítulo muito importante para a história da tradução, da ciência e da língua castelhana: é a primeira vez em que se escolhe esse idioma para traduzir textos científicos, impulsionando, dessa maneira, o desenvolvimento da prosa castelhana, que, por primeira vez, se encontra a expressar conteúdos científicos.

${ }^{4}$ Cfr. Alverny 1989.

${ }^{5}$ No scriptorium afonsino, os tradutores têm quase todos origem judaica (cfr. Hilty 1954, p. XL-XLII): Yehudah ben Moshé ha-Cohen (médico e astrônomo) e Isaac ben Sid (astrônomo) são os mais conhecidos, traduzindo para o castelhano importantes textos astrológicos e astronómicos.

${ }^{6}$ Cfr. Aslanov 2013a, 2013b.
} 
também os textos judeu-espanhóis da tradição italiana, norte-africana, balcânica e turca de época renascentista e moderna. Além disso, há uma riquíssima tradição iídiche em que o hebraico se combina ao idioma germânico, e textos árabes em grafia hebraica que testemunham um importante processo de arabização ocorrido entre os judeus que habitavam os territórios de Dar al-Islam. $^{7}$

Quando falamos em textos românicos de grafia hebraica falamos de textos transliterados, sendo a transliteração aquela prática pela qual se transcreve um texto utilizando-se de um alfabeto que difere do original. Dada a diferença entre os sistemas linguísticos, é necessário cumprir determinados ajustes para que os grafemas de uma língua possam expressar os fonemas de outra; durante esse processo pode ser que haja discrepâncias, que faltem determinados grafemas, ou que sobrem. Por exemplo, no sistema linguístico do hebraico faltam os fonemas /ḑ/ e /3/, e portanto não há grafemas correspondentes: nesse caso, para indicar a pronúncia palatal, a tradição românica se utiliza da letra gimmel (ג) acompanhada por um diacrítico. Existem também situações opostas, em que à riqueza gráfica do hebraico corresponde uma carência de fonemas: $\operatorname{tav}(\Omega)$ e tet, ou teth, (ט), são fonemas distintos em sua língua de origem, e, caso fossem ambos utilizados nos textos em língua românica, representariam o fonema /t/, para os quais se escolhe apenas o grafema tet.

$\mathrm{Na}$ península ibérica apareceram textos em grafia hebraica de diferentes tipologias (escritos científicos e teológicos, textos religiosos, comentários, listas sinonímicas, anotações de caráter administrativo e comercial, entre outros) e variedades hispano-românicas; neste $\operatorname{artigo}^{8}$ abordarei um manuscrito redigido em português e cursivo sefardita, composto no século $\mathrm{XV}$, que trata de medicina e cirurgia. O códice em questão, o Vat. ebr. $372,{ }^{9}$ pertence ao fundo hebraico da Biblioteca Apostólica Vaticana, e considera-se que foi redigido aproximadamente em 1450, mesmo que não se exclua uma data anterior. ${ }^{10}$ A primeira parte do códice é constituída pelo Neseçario, ${ }^{11}$ um tratado de cirurgia atribuído a Samuel Esperel ${ }^{12}$ (também indicado como

\footnotetext{
${ }^{7}$ Para um estudo aprofundado sobre o panorama histórico e sócio-linguístico das línguas judaicas, remeto à leitura de Cyril Aslanov (Aslanov 2011).

${ }^{8}$ Para a apresentação e a transcrição completa do manuscrito, remeto à minha tese de doutorado (Il Necessario di Samuel Esperel trascritto da Yosef Catelan: Edizione e commento linguistico del codice Vat. ebr. 372), defendida em 2017, orientada por Cyril Aslanov (Universidade Hebraica de Jerusalém) e Laura Minervini (Universidade de Macerata/Universidade de Nápoles Federico II).

${ }^{9} \mathrm{O}$ manuscrito é cartáceo, composto por 106 folhas, e sua dimensão é de 215 x 147 mm; para a descrição completa, cfr. Richler: 2008, p. 315. Esse códice foi citado por Matos e Visan (cfr. Matos 2011; Visan 2016) em relação ao corpus de textos portugueses em grafia hebraica.

${ }^{10}$ Proverbio sugere uma data anterior a 1391 (cfr. Proverbio 2003, p. 252).

${ }^{11}$ Ms. Vat. ebr. 372, ff. 1r.-84r.

12 Cfr. BH, p. 1091; Assemani 1756, p. 347; BEPJ, p. 43; Cassuto 1935, pp. 126, 152; Sarton 1948, pp. 1717, 1211, 1233, 1305; Koren 1973, p. 46; Roth 2003, p. 143; Proverbio 2003, p. 252.
} 
Esperial ou Esperil), médico de Córdoba que viveu entre os séculos XIV e XV, ${ }^{13}$ provavelmente bastante conhecido na época, pelo menos nos ambientes judaicos. ${ }^{14} \mathrm{O}$ texto é dedicado a Mestre David, ${ }^{15}$ cirurgião de Jaen, e, como se pode ler na parte final do texto, foi copiado por uso pessoal por Yosef Catelan. A segunda parte do códice, ${ }^{16}$ copiada pelo mesmo Catelan, reúne textos médicos sobre remédios e doenças. ${ }^{17}$

$\mathrm{Na}$ primeira página do manuscrito aparece a descrição do códice que fala de idioma chatalanicum, ${ }^{18}$ provavelmente por mão de Giulio Bartolocci ${ }^{19}$ (1613-1686), Scriptor Hebraicus da Biblioteca Vaticana a partir de 1650; a descrição de Assemani ${ }^{20}$ também fala de língua catalã, enquanto outros estudiosos dizem que se trata de língua espanhola. ${ }^{21} \mathrm{O}$ fato de confundir o português arcaico, língua desse manuscrito, com a língua castelhana é algo comum: o português e o castelhano daquela época se revelam bastante próximos, porque ainda não haviam ocorrido as evoluções fonológicas e morfológicas que os distanciariam. Esse texto registra uma fase da língua anterior às evoluções fonológicas que caracterizam o português clássico: encontramos, por exemplo, a forma non em lugar de não, ${ }^{22}$ como aconteceria em textos posteriores, porque a evolução do ditongo ainda não havia sido registrada na grafia.

O Neseçario foi originariamente composto em uma língua que provavelmente não era o português, possivelmente em castelhano, mesmo que não se exclua o hebraico; o texto é organizado em seis partes, que consistem em uma introdução e nas assim chamadas universalidades; se inicia com uma dedicatória, em que são nomeados o autor e o destinatário, enquanto no colophon são registradas as informações sobre o copista:

\footnotetext{
${ }^{13}$ Cfr. Sarton 1948, p. 1717.

14 Há registro desse nome no manuscrito 14 do Fundo Azevedo da Biblioteca do Porto, redigido em língua castelhana e grafia hebraica; as receitas de Samuel Esperel seguem uma versão castelhana do Thesaurus Pauperum de Pedro Hispano. Para a transcrição completa e o estudo crítico desse código, cfr. Soares de Carvalho Mendes 1999.

15 Um rabino, segundo Sarton (cfr. Sarton 1948, p. 1717).

${ }^{16}$ Ms. Vat. ebr. 372, ff. 84r.-92r. Existe uma terceira parte (ff. 92r.-104v.) em grafia latina, que consiste em um receituário médico, ao qual é atribuído o título Virtudes de lilio laudes.

${ }^{17}$ Nesta seção são nomeados Avicena, Lanfranco de Milão, Teodorico Borgognoni e Guy de Chauliac.

18 De Chirurgia Codex idiomate chatalanico compositus et hebraico charactere conscriptus per Samuelem Sperelem. It[em]: De Medicina tractatus Isaachi Ismaelita pag. 89 et in fine libri usque ad pag. 92 adest Receptarium Chatalanico pro diversis infirmitatibus causis (cfr. ms. Vat. ebr. 372, f. I).

19 Cfr. Ms. Vat. Lat. 13196.

${ }^{20}$ Cfr. Assemani 1756, p. 347.

21 Cfr. Cassutto 1935, p. 126.

${ }^{22}$ No Livro de como se fazem as cores (ms. Parma 1959), o texto mais conhecido do corpus em língua portuguesa e grafia hebraica, a forma naao (נאאו) é usada com mais frequência do que a forma non (נון), cujo uso é exclusivo no Vat. ebr. 372, como também em outros códigos da mesma tradição — outro exemplo é o ms. Laud. Or. 282, ff. 1r.-84v. (cfr. Duchowny 2007, 2014). Sobre o Livro de como se fazem as cores, cfr. Blondheim, 1928, 1930; Strolovitch 2005; Castro 2010; Matos 2011.
} 
אקי קומיסא או נישיסריאו קי קונפוש מיאישטרי שמואל אישפיריל אלמוי אונרדו אי נבלי וארון מאישטרי דוד סירוג'אנו די ג'אין

Aqui começa o Neseçario que compus mestre Samuel Esperel al mui honrado e noble varon mestre David cirujano de Jaen. ${ }^{23}$

אקי שי אקאבא אקינטא אוניבירשידאדי אי קון אילא שי אקאבא או ליברו קי אי נומיאדו או ניסישאריו אין אה סירוג׳יא תל אמן: אישטי ליברו נישיסאיירו אי די יוסף קטילאן אומוסו אי פור שיאיר סירטו אשיניי אקי מיאו נומי יוסף קטילאן

Aqui se acaba a quinta universidade e con ela se acaba o livro que é nomeado o Neseçario en a cirurgia louvado seja o Senhor do Universo Amen. Esto livro Neseçairo é de Yosef Catelan o moço e por seer certo as[s]inei aqui meu nome Yosef Catelan. $^{24}$

De um ponto de vista temático, o Neseçario constitui uma coletânea de saberes médicos e procedimentos cirúrgicos bastante divulgados na época, remetendo às doutrinas da antiguidade grega (Hipócrates e Galeno), e da tradição islâmica (Avicena e Abulcasis). ${ }^{25}$

A prática médica se modificou muito ao longo dos milênios, e, antes de Hipócrates (c. 460-375 a.C.), a medicina da Grécia Antiga propunha-se sobretudo à esfera do sobrenatural e do divino, bem distante de uma iatriké téchne desenvolvida a partir da abordagem científica. Hipócrates rompe com as tradições anteriores, tornando a medicina uma prática racional baseada na observação clínica e no método científico.

A condição de saúde se pensava que derivasse de um estado de equilíbrio do corpo, e, quando esse equilíbrio era comprometido, surgia a doença; no corpus hippocraticum, um conjunto de por volta de sessenta tratados atribuídos aos sucessores de Hipócrates, é apresentada a teoria humoral, elaborada e ampliada, mais tarde, por Galeno. No Neseçario muitas são as referências à doutrina humoral — há também um desenho que ilustra as possíveis combinações das qualidades de quente, frio, úmido e $\operatorname{seco}^{26}$ - como também a Hipócrates e Galeno.

\footnotetext{
${ }^{23}$ Cfr. ms. Vat. ebr. 372, f. 1r.

${ }^{24}$ Ivi, f. 84r.

${ }^{25}$ Avicenna é chamado exclusivamente Ibn Cina, enquanto Abucasin é citado segundo o uso latino, a exceção de uma ocorrência, em que é chamado Abulcacim Azharaui (ivi, f. 52v.); para Hipócrates se usa o árabe Abucrat (Hipocrates aparece só uma vez, ivi, 11v.).

${ }^{26} \mathrm{Ivi}, \mathrm{f} .2 \mathrm{v}$.
} 
A Galeno (c. 129-199 d.C.) vai o mérito de ter elaborado os conhecimentos hipocráticos, e aprimorado a teoria humoral, partindo sempre de uma observação do corpo e dos princípios anatômicos, e utilizando-se de métodos demonstrativos; além disso, foi o primeiro a dizer que o sangue corre também nas artérias, em que se pensava que passasse o ar.

דיגו קי או אישפאשמו אקאיסי אינא ג'אגא פור ג' ראזואיש או פור גראנדי וואזייאמינטו די שנגרי. אי פור גראנדי דואור קי וינייא אאה פונסאדורא. או פור פונסידאד קי אביני אינו פ’ירו קי פ'יזו אה ג'אגא. אי קומו קיר קי טודו אישפאשמו קי וייני קון ג'אגא אי מורטאל שיגונגו דיזי אבוקרט

Digo que o espasmo acaece ena chaga por tres razoes o porgrande vazeamento de sangre, e por grande door que venha aa punçadura, o por puncedad que avene eno fer[r]o que fizo a chaga, e como quer que todo espasmo que viene con chaga é mortal segundo dize Abucrat. $^{27}$

אי דישי אבוקראט פוניאן שוברי או נימברו קיבראדו או סירודו. קי אי קונפושטו די סירא אי אזייטי רושאדו.

E dis[s]e Abucrat ponhan sobre o nembro quebrado o cerudo, que é conposto de cera e azeite rosado. $^{28}$

אה מניירא דא קושטורא אשי קומו דישו גאליינו קונביני קי שיג'א אה קושטורא שיגונדו אה גראנדיזא דא פינדידורא

A maneira da costura asi como dis[s]so Galeno convene que seja a costura segundo a grandeza da fendedura. ${ }^{29}$

אישטי אי או טישטו די גליינו נישטא ראזון. קונבין קי מיטאש אה אגולייא אינא אורילייא דו מיראק סירקאנא אטי די פואירא אי פאשא אה די פורא. פ’אז אדינטרו אינילא אין שיאו קאבן. אי דישאר לא אורילייא דו סיפאק דישי טורנא אה אגולייא די פ'ורא אדינטרו אינאש דואש אוריליאש דו סיפאק.

\footnotetext{
${ }^{27} I v i$, ff. 37r.-v.

${ }^{28} I v i$, f. $49 \mathrm{v}$.

${ }^{29}$ Ivi, f. 21 r.
} 
Este é o testo de Galeno nesta razon, conven que metas a agulha ena orelha do miraq ${ }^{30}$ cercana até de fuera e pas[s]a-a de fora, faz adentro enela en seu cabo, e dexar la orelha do cifaq $^{31}$ des[s]e torna a agulha de fora adentro enas duas orelhas do cifaq. ${ }^{32}$

As contribuições de Hipócrates e Galeno tiveram uma influência profunda no mundo islâmico, e os médicos orientais desenvolveriam sua medicina a partir dessas noções. $\mathrm{O}$ hispano-árabe Abu al-Qasim al-Zahrawi (936-1013) - Abulcasis ou Abulcasim, segundo o nome latino - , foi o primeiro a organizar noções sobre cirurgia em uma extraordinária obra enciclopédica chamada Kitab al-Tasrif, conhecida como $O$ método da medicina. Os textos de Abulcasis, traduzidos para o latim por Gerardo de Cremona (1114-1187), são muito detalhados e fornecem importantes contribuições para a elaboração de instrumentos cirúrgicos durante toda a Idade Média - nos manuscritos latinos foram transmitidas também suas ilustrações. No Neseçario, Abulcasis é nomeado em relação aos instrumentos cirúrgicos e a outras práticas:

מאיש אבוקשין דישו קי איל קבטיריו קון או פ'ירו אי מיליור אי מאיש דירייטו פור קי שי פ'ונדי די גראבי. אי פור קי או אורו שי פ'ונדי די ליג'יירו.

Mais Abucasin dis[s]o que el cauterio con o fer[r]o é melhor e mais direito porque se fonde de grave, e por que o oro se fonde de ligeiro. ${ }^{33}$

אי דישי אבוקשין אקאיסי אינא גרגאנטא אפושטימא גראנדי די קואור דא קרני דו קורפו. אי או מאיש אינאש מוליריש. אי אי די ב' מניירש אסידינטאל אי נטוראל.

E dis[s]e Abucasin acaece en a garganta apostema grande de coor da carne do corpo, e o mais enas mulheres, e é de duas maneiras acidental e natural. ${ }^{34}$

\footnotetext{
${ }^{30}$ Por miraq se entende a parte superficial da parede abdominal (cfr. Herrera, Vázquez de Benito 1981, pp. 161164.)

${ }^{31}$ Por cifaq se entende "peritônio" (cfr. Herrera, Vázquez de Benito 1982, pp. 183-186).

${ }^{32}$ Cfr. ms. Vat. ebr. 372, f. 21v.

${ }^{33}$ Ivi, $13 \mathrm{v}$.

${ }^{34}$ Ivi, f. 80r.
} 
אי דישי אבוקראט אי אבולקאסים אזהראוי. אי אין או קי קונבין אטי קי טי ריטינייאש. אי קונב'ין קי שיג'אש סירטו אין טיאו אינטינדימינטו קי קואנדו שי קיבראנטארי אושו גראנדי אשי קומו אושו די קושא. אואו די אירמון קי נון פוניאש די או טיראר אי די או שקאר קא מויטש ויזיש שילי שיגי פור אינדי אמורטי.

E dis[s]e Abucrat e Abulcacim Azharaui, e en o que conven até que te retenhas, e conven que sejas certo en teu entendimento que quando se quebrantare os[s]o grande asi como os[s]o de coxa, ou de $[\ldots]^{35}$ que non ponhas de o tirar e de o sacar ca muitas vezes se le segue por ende a morte. ${ }^{36}$

Ibn Sina, (980-1037), conhecido também como Avicena, é a outra fonte árabe nomeada no Vat. ebr. 372; entre as muitas habilidades, foi médico, filósofo e matemático, constituindo um dos autores mais prolíficos da história científica do Islã. Contribuiu de forma inestimável para a medicina oriental e ocidental, redigindo o Kitab al-Qanun - o famoso Cânone da medicina -, obra extensa que organiza o saber científico desde Hipócrates e Galeno até os autores coevos, e que Gerardo de Cremona traduziria mais tarde para o latim.

דישו ן' סינא אקיאין אקאיסירי פירידא. או קאידא אי שי דישטאליארי שואה פאלאברא. אי שי טורסירי שואה קביסא אי שוארי שואה פ'רונטי אי אמארילייסירי שואה פ'אז אי אינבירדיסירי מורירא לוגו.

Dis[s]o Ibn Cina a queen acaecere ferida, o caida e se destalhare sua palabra, e se torcere sua cabeça e suare sua fronte e amarelhecer sua faz e enverdecere mor[r]erá logo. ${ }^{37}$

או ב' אי אשי קומו דישו ן' סינא שי או נירביו פירפונסאדו קי נון אי אשיגוראדו די אישפאשמו קא דיזי גליינו אה אפושטימ. אי טורנאדא אאו נירביו אאה פארטי נון טאליאדא אי אה ראזון פורקי שי אישטירא או נירביו אגאון קאבו אי איל אוטרו אל אוטרו קאבו קא שיגין שיליי מויטש ויזיש מאאוש אסידינטיש אי אישפאשמו.

\footnotetext{
${ }^{35}$ No texto se lê a palavra אירמון ('yrmwn).

${ }^{36} I v i$, ff. $52 \mathrm{v} .-53 \mathrm{r}$.

${ }^{37} \mathrm{Ivi}$, f. $27 \mathrm{r}$.
} 
O segundo é asi como dis[s]o Ibn Cina se o nervio perpunçado que non é asegurado de espasmo ca dize Galeno a apostem[a] é tornada aao nervio aa parte non talhada e a razon porque se estira o nervio agun cabo e el otro al otro cabo ca seguen se-lhe muitas vezes maaus acidentes e espasmo. ${ }^{38}$

Outro nome citado é o de Teodorico Borgognoni (1205-1298), autor do Cyrurgia seufilia principis, que, ao lado de seu pai, mestre Ugo, foi um dos médicos italianos mais importantes do século XIII. Pai e filho adquiriram grande fama na Faculdade de medicina de Bolonha, uma das maiores na Europa medieval, juntos com os centros de Salerno, Paris e Montpellier, distinguindo-se pelas contribuições sobre o tratamento anti-séptico das feridas e a prática anestésica.

אי דישי טדריק. קי אילי קורו טודו קורימינטו די שאנגרי קי ויאו אאיל פור ראזון די פ'ורא פור אה מניירא קי נוש דישימוש פרימיירו. אי קי איל נון אובו מיאישטיר אושאר אוטרא קואושא:

E dis[s]e Tadreq, que ele curó todo cor[r]imento de sangre que veo a el por razon de fora por a maneira que nos dis[s]emos primeiro, e que el non hubo meister usar otra cousa. ${ }^{39}$

מאיש אונו דוש פושטרימירוש קי אה נומי טדריק קונפילו און ליברו בואו אינא קורא דאש ג'אגש אי אי נוטוריאו: אי דישי איניל אין נומי די מ' אוגו שיאו מאישטרי קורא דוש קיבראנטאמינטוש דוש אושוש דא קביסא פור אוטרא מאניירא קי אה די גליינו.

Mais uno dos postrimeros que a nome Tadreq compiló un livro boo ena cura das chagas e é notorio. E dis[s]e enel en nome de M[estre] Ugo seu Mestre cura dos quebrantamentos dos os[s]os da cabeça por otra maneira que a de Galeno. ${ }^{40}$

Considerando essa breve introdução às fontes médicas do Neseçario, vemos como nos séculos da Idade Média se opera uma verdadeira síntese do saber científico, reunindo noções antigas, práticas provenientes do mundo árabe e dos centros europeus. O léxico é extremamente rico, apresentando um português em via de formação, influenciado por termos castelhanos, que

\footnotetext{
${ }^{38} I v i$, ff. $36 \mathrm{r} .-36 \mathrm{v}$.

${ }^{39}$ Ivi, f. 20v.

${ }^{40}$ Ff. 34r.-34v.
} 
se utiliza do árabe para expressar um vocabulário específico, relativo ao mundo das plantas e dos minerais, à complexidade do corpo humano.

Antes de deixar a leitora e o leitor ao texto, concluo dizendo que o Neseçario pode ser abordado a partir de diferentes perspectivas: de um ponto de vista linguístico e filológico, se destaca a sua importância por ser um dos poucos testemunhos que integram o corpus exíguo de textos portugueses em grafia hebraica, fundamental, então, para ampliar o espectro de análise, estabelecendo pontos de contato e divergência com textos da mesma tradição. Além disso, refletindo sobre aspectos mais técnicos, podemos dizer que um documento desse tipo se revela precioso para a reflexão linguística, registrando uma língua in fieri, com seus usos e oscilações, em que a transliteração, por se utilizar de uma grafia diferente do sistema fonológico da língua que expressa, é capaz de flagrar aspectos da fala que, por outro lado, poderiam ser homologados segundo os costumes gráficos durante o processo de escrita. Partindo de uma perspectiva histórico-cultural, esse tratado constitui um documento que fala a respeito da atividade médica nos ambientes judaicos da península ibérica, e, resumindo saberes científicos anteriores e coevos, se torna um importante elo entre as experiências médicas medievais e as práticas renascentistas.

Uma obra transliterada, enfim, é uma criação fascinante, singular e complexa, e sua importância, além do valor intrínseco do testemunho que representa, reside na síntese que opera: reunindo sistemas linguísticos distantes, reúne também diferentes universos culturais, que implicam diversas formas de ver e pensar o mundo.

Seguem-se os primeiros capítulos do Neseçario, em grafias hebraica e latina. ${ }^{41}$

[f. 1r.]

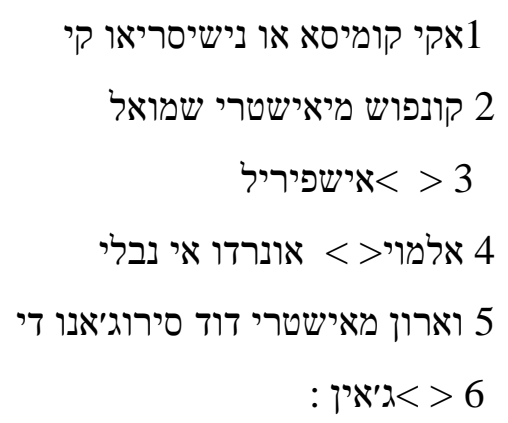

\footnotetext{
${ }^{41}$ Os símbolos $<>$ indicam um espaço no texto original, enquanto as barras $\backslash$ / indicam que o texto é escrito acima da linha; os colchetes introduzem acréscimos. Para o texto em grafia latina me utilizei, por vezes, das maiúsculas e, por meio do acento agudo, fiz a distinção entre $e$ conjunção e é verbo. 
7 דימי מאישטרי שמואל פישיקי די קורדובא ווש אינביו

8 מוייטו שאודאר קומו אאומי קי אמו .אי פירא קין 9 קיריאה קי דיאוש דיאישי מויטא אונרא אי בואה וינטורא

10 אי אבונדאנסיאה אי פור אינדי איאו אמאנדו קונפליר 11אלגואה קואושא דוש וושוש דישיגיש קי מי רוגאשטי/ש| 12קי ווש אישקריבישי אלגואש ליטראש אינאש קונפלישו/איש 13 בריבי מינטי .איאו אינביו ווש אישטש פישטולטש 14פלאבראש בריביש אי פארטיאש אג' קאפיטולוש: 15קפיטולו פרימיירו פאבלא אינוש קונפלישיואי/ש| 16 > >אי אינשיאו דיפיניסיון אוני 17 17ירשלמינטי: 18קאפיטולו ב' פ'אלא דאש שינאאיש די טודאש אש 19 >>>ונפלישיואיש אישפיסיל מינטי: 20 קאפיטולו ג' פ'אלא קומו שי דיב'ין ג'ולגר אש קונפלישיו/איש

1אי קואאש שין אש קואושש קי דיבי אומי קטאר. 2 קואנדו אובירי די ג'ורגאר אה קונפילישון אי אגורא 3קומינסארי אדיזיר קון אג'ודא די דיאוש מיאו שיניור: 4 קפיטולו פרימיירו קי פ'אלא אוניבירשאל 5 מינטי אינא קונפלישון אי אינשיאו

6 דיפייניסיון :דישו ן’ סינא אה קונפלישון אי קואלי 7 >> דאדי קי קונטיסי פור פ'אזימינטו די

8 קולידאדי/ש \קונטראיירש אג'אדש אינוש אילימינטוש מויי 9 פיקינאש אש פארטיש פורקי שי מיסקלין מילייור אש 10אונאש קון אש אויטראש :קיר דיזיר קי טודאש אש 11קוישאש דישטי מונדו הושאנו42 שון קונפושטאש די 12ד' אלימינטוש קי שון פ'וגו אי אר אי אגואה אי טירא. 13דישטא מאניירא קי קון שיאוש מובימינטוש פאזין/ אוש| 14אונוש אינוש אויטרוש. אי פ'אזין דונדי אוש קורפו/שו. 15אי אה קאלידאדי קי וימוש קי וינסי מאיש קי אש

42 Transcrevo a palavra assim como aparece no manuscrito; em geral, he em posição inicial é pouco usado nesse tipo de texto, sendo utilizado sobretudo alef. Acredito que shin esteja escrito no lugar de mem. 
16אויטראש ג'אמאמוש אאקילי קורפו פור אקילא קואלי

17דאדי אי נון נומיאמוש אש אואוטרש קיאלידאדיש40 18אי פור אישטו דישי ן’ סירא קאלידאדי קי קונטיסי:

19אי אישטש קאלידאדיש שי פארטין אב' פארטיש אין

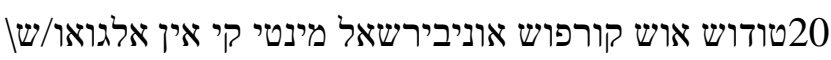
21אי פוטינסיאל אי אין אלגואוש אי אקטואל .מאיש 22אוש קורפוש אינקי אי פוטינסיאל שון אשי קומו

$w_{N}<>$

1 אש פרנטש אי אש מיניוראש .אי נוש נון קירימוש 2 פאלאר דו פוטינסיאל .מאש אוש קורפוש אי אקטואל

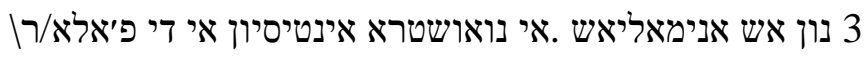
4איניל אומין פרופיאה מינטי .אי אש קונפלישואיש 5 שיגונדו אש פארטיאו גאליאינו שון ט' אה אואה 6 איגואל אי אש אוייטו נון איגואאיש .מאיש או איגואל 7 דיזין די מויטש מאנייראש קי אאוראש או דיזין אאונא 8 קואושא ארישפיקטו די אוטרא אשי קומו דיזין קי 9 איש איגואל או אומין ארישפיקטו די טודאש אש 10 אויטרש קואושש .אי אאוראש דיזין: 11 איגואל ארישפיקטו די שואה אישפיסיא אשי קומו דיזי 12 איגואל אי אישטי ליאון ארישפיקטו די טודוש אוש ליאו/ניש \וגו 13 אה אישטי אומין שיגונדו טודוש אוש אומיאיש .אי 14 אישטא אי נושא אינטינסיון דו איגואל .אי אאוראש שומשוש 15 לו דיזין אישטי איגואל אאו קונפושטו דאש ד' קואלידא/דישו 16 קי נון פוג׳י. ניניואה דילאש שוברי אה אויטרא אי 17 אישטו שיגונדו אוש פ'ילושופ'וש נון פודי שיאיר. 18 מאיש אש אויטו נון איגואאיש אש ד' שון שינפליש 19 אי אש קואטרו קונפושטש .מאש אש שינפליש 20 שון אשי .קואנדו אג'ארמוש אין און אומין קי

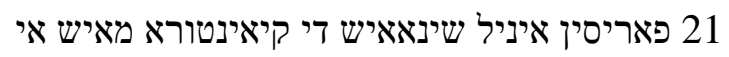
22 אג'ארמוש אה שיקידאדי קון אה אומידאדי איגואל

43 O primeiro yod é para se considerar um waw. 
23 מינטי דירימוש אאקיל קורפו קיאינטי .שינפלימינ/טי |

24 אי אשי פ'ארימוש אין קאדא אואה דש אויטראש

[f. 2v.]

1 טריש קואלידאדיש.מאש אש קואטרו קונפושטאש שון

2 אשי קומו קואנדו אג'ארמוש שינאאיש די דוש קואלי

3 דאדיש קי וינסין אי שון קיאינטי אי שיקו קיאינטי אי

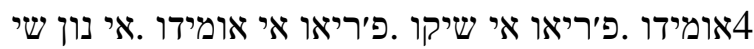
5 פודי קונפואיר דוש קואטרו אלאימינטוש מאש דישטוש 6 קי קונטאמוש קא שירא איגואל אי נון איגואל .אי אי אשי 7 קומו קונטאמוש .אי קירימוש אקי פ'אזין אואה 8 פ׳יגורא פור קי שי אינטינדא מאיש אישטא מניירא 9 קומו אי או שינפליש אי או קונפושטו. אי קואל שי קונפון 10 קון קואל אי קואל נון .אי אישטא אי אה פ'יגורא 11 12 קי נושא

13 אינטיסיון 14 אי די פ'אלאר 15 בריבי מינטי 16 קירימוש אקי 17 אקאבר אישטי

18 פרימיירו קאפיטו/לון

19 אי פאלאר

20אינו שיגונדו: - (אינ:

21 קפיטולו שיגונדו פ'אלא דש שינאאיש די

> > >ודאש אש 22

23 קונפלישואיש :אש שינאאיש די טודש אש קונפלישיו/איש|

>> שי פארטין

44 O texto é ilegível por causa de uma mancha de tinta; há duas palavras, e no caso da primeira acredito que se trate de partes. 
2 נימברוש דו שינטידו אי אש אויטראש דא וירטודי 3 וידאל. אי אש אויטראש שי טומאן דוש מימרוש 4 דו גובירנו .אי אש אויטראש טומאן דוש נימרוש דא 5 אינג׳ינדראסון. אי איאו פור ראזון די אבריביאר אי 6אי פור קי שיג'א מאש אג'יגאדוש אאו שישו דו קי 7 או קישיר אפרינדיר. פורני אליגאדא מינטי אש 8 שינאאיש די טודוש אישטוש מימרוש אקאדא 9 אואה דאש קונפרישיואיש. אי קומינסאר דאש 10 שינפליש אי דיפויש איריא. אאש קונפושטאש. אי זישי 11 אישטו אי שיגונדו אורדין .דיגו קי שי פ'ור קיאינטי 12 שירא די שינטירו שוטילאי אגודו אי אפרישורושו 13 אין שי או פ'אלאר אין טודאש שואש קושאש אי אין 14 טודוש שיאוש מובימינטוש. אי אה וירטודי וידאל 15 אינילי פורטי. קי שירא שאניושו אי אטריבידו אי 16 באראלייאדור .אי נון מידרושו אי אש וירטודיש דו 17 גובירנו פ'ורטיש אינילי. אשי קומו אביר שאב'ור 18 די קומיר בין. אי קוזיר בין אויאנדא. אי אב'יר מאיש 19 קארניש קי נון גרושורא נין שיבו. אי מויטוש קאבי/לוש| 20פור טודו או קורפו. אי בירמילייו או קואור די שואה 21 קארא. אי אה וירטודי דא ג׳יאיראסון אינילי פורטי. 22 אי שי פ'ורי פ'ריאו שיאוש שינאאיש שון קונטראיי/רש| 23 אאש דו קיאינטי אשי קומו די שישו טורפי אי נון 24 אי שוטיל נין אגודו. אי וואגארושו אין טודש שואש

1 קואושש טאן בין אין פ'אל[...]45 אינוש אוייטר 2 מוב׳ימינטוש .אי אה וירטודי[ וי]דאל46 אינילי פלאקא: 3 טארדי שאניושו או נונקא .מאנשו אין טודאש שואש 4 מאניירש .אי מידרושו .אי אש וירטודיש דו גובירנו 5 פלאקש אינילי נון אביר שאבור בין די קומיר .נון די 6 קוזיר בין אה ויאנדא. אי אביר מאיש שיבו קי קארניש.

45 Texto ilegível.

46 Os primeiros dois grafemas são ilegíveis, acredito, porém, que se trate da sequência waw-yod. 
7 אי אוש קאבילוש די שיאו קורפו או קי שיג'אן פואוקוש 8 אי שי פ'ורין קי שיג'אן בלאנקוש .או קי טירין אבלאנקו/שו 9 אי ליזניש דילגאדוש אי פ'לאקוש. שי לי

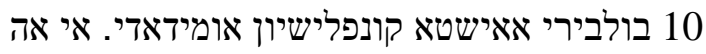
11 וירטודי דא אינג׳ינדראסיון אי נילי פ'לאקא. אי קואנדו 12 פ'ורי אומידו שירא טורפי מויי אולבידאדו. מויי דו/רו

13 מידור אי נון אישפירטו פירא אש קואושש. אי אה 14 וירטודי וידאל דישטא מניירא. או פולשו בראנדו 15 אי אילי אג'יגייא אינשאנייארשי אי אגייגייא טורנאר/שיו 16 אי אאינדא שירא מידרושו אי אה וירטודי גובירנאנ/טיו 17 שירא אינילי דישטא מניירא. אש ויאש די טודו שיאו 18 קורפו שיראן בלאנדאש אי טירא מוי/ט|א קארני אי מוי/טו|

19 שיבו אי טודו שיאו קורפו בלאנדו. אי קי שובראן 20 איניל מויטש אומידאדיש. אי או קאבילו דילי בלאנדו 21 אי אה וירטודי דא אינג'נדראסון אינילי פ'לאקא. אי 22 די מאיש שי בילב'ירי קואילי פ'ריואורא. קא שירא איניל 23 אישפירמא מויי דילואדא קורינטי. אי שי פ'ורי שיקו 24 שיאוש שינאאיש שון קונטרארייאש אאישטש דו

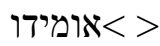

1 אומידו. אשי קומו אקורדארשי בין אאש קואושש. 2 אי נון שיאיר דורמידור אי שיאיר אישפירטו פירלש 3 קואושש. אי אש אויטראש וירטודיש אינילי קונטר 4ארייאש. אאש דו אומידו פור אישטא מניירא. 5 אגורא אבימוש דיטו אש שינאאיש דאש קואטרו 6 קונפלישיואיש שינפליש. מאיש אש ד' קונפושטש 7 אינטינדינשי דאש שינפליש. מאיש פור ראזון קי 8 שי אינטינדא מיליור דיריאיי אלגואה קואושא בריבי 9 מינטרי. שי או קורפו פורי קיאינטי אי אומידו 10 שיאוש שינאאיש שון אישטש. שירא די בואו שישו 11 אי די מוייטו דורמיר אינטרי מיאאו אינטרי באגא/רושו| 21 או אפרישורושו אי די מויטוש שונוש אי אה וירטו/די 
31 וידאל אי נילי קומונאל .אג'ונייא שאניושו או אגונייא

41 אפ'אגאדו. אי שיאו פולשו גראנדי אי בלאנדו אי

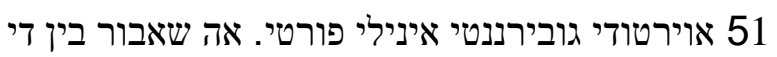
61 קומיר. אי קוזי בין אה ויאנדא. אי אברא מוייטא/ש| 71 קארניש אי מוייטו שיבו אי טודו שיאו קורפו קיאינ/טיו 81 בראנדו. אנג'אש אש ויאש אי בראנדאש .אי אוש 91 קאבילוש די שיאו קורפו שיראן מויטוש אי בראנדוש 20 אי אה וירטודי דא אינגינדראסון שירא פורטי שי נון

12 קי אי קורינטי שואה אישפירמא. אי אש שינאאיש 22 דו פ'ריאו אי שיקו שון שואש קונטראריאש דישטש 32 דיטש. מאיש אש שינאאיש דו קיאינטי אי שיקו 42 אי אש שינאאיש דו פ'ריאו אי אומידו פור אישטא

1 2 קונפוניראש .מאיש אש שינאאיש דו טינפראדו

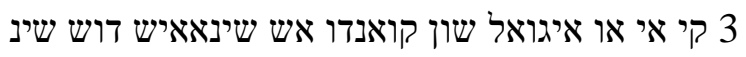
4פליש נון פוג׳אן אש אואש שוברי אש אוייטראש. 5 אי פאזי טודאש אש אובראש נטוראאיש קונפרידא 6 מינטי .אין או מיליור קי פושא שיאיר אינא אישפי 7 סייא דו אומין .אי אגורא אבימוש דיטו אש שינאאי/ש 8 דאש קונפלישיואיש בריבי מינטי .אי אגורא דירימו/ש| 9 קומו שי דיבין ג'ורגאר אישטש קונפלישיואיש: 10 קאפיטולו טירסיירו קומו אי אה מניירא > > > ג'ולגאר אה קונפלישון 11 12 אי קי שון אש קואושש קי דיבי אומיץ/ די \קטאר קואנדו 13 קישיר ג'ורגאר .אה מניירא די ג'ולגאר אה קונפלישון 14 דיבי שיאיר אישטא .דיבימוש טומאר טודאש אש 15 שינאאיש דא קונפלישון טינפראדא אי מג'ינאראש 16 אנטי אוש אוליוש .אי ויאר אקואל קואלידאד שי 17 אינקולגאן אש שינאאיש אי אשי ג'ורגארימוש.אי 18 שי וירמוש קי פאריסין אקילש שינאאיש.קי שי

47 Talvez se trate da sequência dalet-waw-yod. 
19 אינקלינאן אה אלגואה קואלידאדי פורטי מינטרי .ג'ול

20 גארימוש קי אי מוייטו שאידו דא איגואלדאדי .אי 21 שי פ'ורין פ'לאקש אש שינאאיש ג'ורגארימוט קי אי

22 פואוקו שאידו דא איגואלדאדי .אי דיבימוש קטאר 23 קואנדו קישירמוש ג'ולגאר אישטא אינקליסון אין ג' 23 קואושש .אה פרימיירא אש קואושש נאטוראיש אה

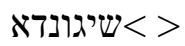

1 שיגונדא אש קואושש נון נאטוראיש .אה ג' אש קואו/שש| 2 פורא די נטורא .קי קאדא קואושא דישטש דימודא 3 אה קונפלישון .קא אש קואושש דימודאן אה קונפלי 4 שון פור ד' מנייראש .אה א' שיגונדו דישב'אריאמינטו

5 דוש מימרוש .אה ב' שיגונדו אש אידאדיש .אה ג' 6 שיגונדו אש/אי \קלימש .אה ד' שיגונדו או מאגו אי אה 7 פ'ימייא .אי קונביני קי פ'אלימוש אלגון פואוקו איניש

8 טאש קואושש.או דישבאריאמינטו דוש נימרוש אי 9 אין ב' מנייראש .קא איל א' אי איגואל אי או אוטרו 10 נון איגואל .אי או איגואל דישבאריאמינטו אי אקיל קי 11 שון שיאוש מימרוש שיגונדו דיבין שיר אוש קיאינטי/ש| 12 קיאינטיש אי אשי אוש אוטרוש .אי איל נון איגואל 13 דישב'אריאמינטו אי אקיל קי שון שיאוש מימרוש 14 קונטראריו דו קי דיבין אשיאיר .אשי קומו אוש קי אן 15 די שיאיר קיאינטיש קי שיג'אן פ'ריאוש .אי אגורא דירי/מוש| 16 דו איגואל דישבאריאמינטו קי שון אינוש מימרוש 17 אי דיפויש ווש אינטינדירידיש או נון איגואל קון אש 18 שינאאיש קי דישימוש די שושו .דיגו קי או מאיש 19 קיאינטי קי אי איניל קורפו דיל אומין אי או אישפריטו 20 וידאל .אי דיפויש או קוראסון קי אי שואה מוראדא 21 דו אישפריאו וידאל .אי קומינסאמינטו דא קאלור 22 נטוראל .אי דיפויש אה שאנגרי .אי דיפויש או פ'יגאדו 23 אי דיפויש אה קארני .אי דיפויש או מושקלו .אי 24 דיפויש או באסו .אי דיפויש אוש ריניואיש .אי דיפוי/ש| 
[f. 5v.]

1 אש פיליש דאש ארטיריאש .אי דיפויש אש פיליש דא/ש| 2 ויאש .אי דיפויש או קויירו .או די טודו או קורפו 3 קי אי טינפיראדו .אי או מאיש טינפיראדו אי איגואל 4 אי או קואירו דא פאלמא :אי אוש מימרוש פ'ריאוש 5 שון אשי .אי מאיש פ'ריאו קי אי אינו קורפו שון או/ש| 6 קאבילוש .אי דיפויש או אושו .אי דיפויש אה טירנילי/א.| 7 אי דיפויש אש פיליג'ואילאש אי דיפויש אוש נירביו/ש.ו 8 דיפויש אה נוקא .דיפויש או מיאולו. דיפויש או שי/בוו. 9 דיפויש או קויירו: אי אוש מימרוש אומידוש 10 שון אישטיש. אה קושא אי מאיש אומידא קי אי אי/נו| 11 קורפו אי אה פ'רימא. דיפויש אה שאנגרי .דיפויש 12 אה גרושורא. אי דיפויש או שיבו .אי דיפויש או 13 מיאולו .דיפויש אה נוקא .דיפויש אה קארני דאש 14 טיטאש אי דוש ג'יניטוריוש .דיפויש או פולמון .די 15 פויש אוש ריניואיש .דיפויש אוש מושקלוש .דיפויש 16 או קויירו .אי אוש מימרוש מאיש שיקוש דו קורפו 17 שון אוש קאבילוש אי דיפויש או אושו. אי דיפויש 18 אה טירנולייא. אי דיפויש אוש אטאדוריש. דיפויש 19 אש קורדאש. דיפויש אש ארטיריאש דיפויש אש 20 ויאש. דיפויש אוש נירביוש דו מובימינטו. דיפויש 21 או קוראסון. דיפויש או נירביו/ש \דו שינטידו. דיפויש 22 או קויירו. אי אגורא אבימוש דיטו אה קונפלישון

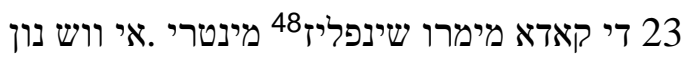
24 אברידיש גראבי די קונפואיר אלו אינשינפלו49 דישטו או

>> > > > > > >

[f. 6r.]

1 קוראסון .(דיפויש או נירביו דו שינטידו דיפויש או קויי/רו).) 2 (אי אגורא אבימוש דיטו אה קונפלישון די קאדא)

48 Neste caso, encontra-se zayin em lugar de shin.

49 Shin é acompanhado pelo diacrítico que indica uma possível variação na pronúncia. 
3 (מימרו שינפלי מינטרי) .אי מאיש קיאינטי קי טודוש 4 אוש אוטרוש מימרוש .אי קין אה אשי שיאוש נימ

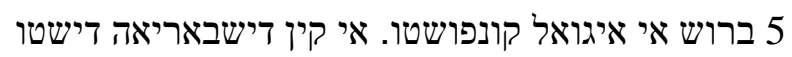

6 אה מאיש או מיאוש נון אי איגואל קונפושטו. אי 7 אה מניירא דו ג'ולגאר אינישטא ראזון אי אשי קי 8 קואנדו אווירדיש או מיאולו אי פ'ריאו קיר דיזיר קי 9 אי מאיש פ'ריאו קי נון דיבי די שיאיר. אי קואנדו 10 אווירדיש או מיאולו אי/ קיאינטי וקיר דיזיר 11/קיאינטי \קי נון דיבי די שיאיר אי אשי אין טודוש אוש

12 אוטרוש מימרוש :אה ב' מניירא דאש קואושש נטו 13 ראאיש קי דימודאן אה קונפלישון שון אש אידאדיש 12 14 אי אש אידאדיש שון קואטרו אה פרימיירא אי 15 דישדי קי נאסי פאשטא50 יד" אנוש. אי קיאינטי אי או/מידו| 16 אה ב' אי פ'אשטא51 ל' או לה" אנוש. אי אי קיאינטי אי

17 שיקו אה ג' אי פ'אשטא ס' אנוש. אי אי פ'ריאו אי שי/קו . 18 אה ד' אי פ'שטא אה מורטי .אי אי שיגונדו נטורא 19 מאיש פ'ריאו אי מאיש שיקו קי אה טירציירא אידאדי 20 מאיש פור ראזון קי שי אינג'נדראן אינילי מויטש 21 שיפורפ'ולידאדיש ג'ולגאן קי אי מאיש פ'ריאו אי אומי/דאדו| 22 אה ג' מניירא דאש קושאש נטוראאיש קי דימודאן 23 אש קונפלישואיש קי אי שיגונדאו אש/ אקלימאש52: אי 24 אש קלימש שון ז'. אי אוש קי מוראן אינא לינייא

1 דא איגואלדאדי קי ויינא די מוריאינטי אה פונינטי .אי אוש 2 קי מוראן סירקא אשי קומו אוש קי מוראן איגא קלימא 3 ד'.אינישטש קונייסירטאן אש שינאאיש דאש קונפלישו/איש| 4דיטאש :מאיש אוש קי מוראן אלישאדוש דא לינייא דא 5 איגואלדאדי אקואל קאבו קיירא .או קי קי שיראן מוי בלאנ/קוש| 6 אדימאש דא גראנדי פ'ריאור. או קי שיראן קימאדוש ניג/רוש| 7 דא גראנדי קיאינטורא. פואיש אה מניירא דו ג'ולגאר

50 Acima do grafema pe se encontra o rafeh, que indica a pronúncia da fricativa labiodental.

51 Desta vez, acima de pe não há o rafeh, mas o ponto, como aparece na quase totalidade dos casos.

52 A palavra climas é precedida por alef. 
8 אינישטא ראזון .אי אשי קי אאינדא קי ווש ויג'אדיש 9 אקיל קימאדו ניג'רו53 אי שיאוש קבילוש ניגרוש אי קי קרי

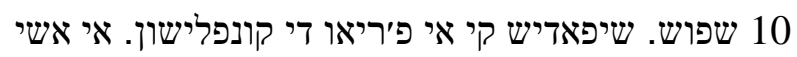
11 אין אוש אויטרוש מויי בלאנקוש קי שון קיאינטיש 12 קונפלישון אאינדא קי ווש לווידיש די קאבילוש ליזניו/שו 13 אי מויי פוקוש. מאיש פירא ווש גולגאר דירייטא 14 מינטרי פראגמינטיש קואל אי או טינפראדו אין קאד/א| 15 קלימא. אי דאקיל אינטינדירידיש טודוש לוש די שואה 16 קלימש. אה ד' מאניירא דאש קואושש נאטוראאיש

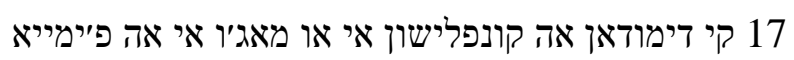
18 אי אישטא מניירא קי אה פ'ימייא אי מאיש פ'ריאה 19 אי מאיש אומידא קי או מאג'ו. פויש אה מניירא 20 דו גולגאר אינישטא ראזון אי קי ווש מאגינידיש אה 21 מאיש אגייגאדא איגואלדאדי אינטרי טודאש אש 22 מולייריש. אי די אקילא טומאר אינטינדימ. פירא 23 אש אוטרש טודאש אי אגורא אבימוש אקאבאדו 27 אש קושאש נאטוראיש קי דימודאן אה קונפלישיון מאיש

1 מאיש אש קואושש נון נאטוראיש שון ו' אי שון אואיי/ריו

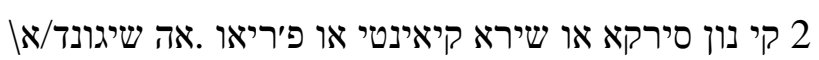

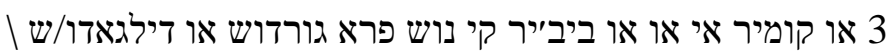
4או פריאוש או קיאינטיש .אי אה טירסיירא או מובימי 5 נטו אי קידאמינטו קי או מובימינטו שי אי מוייטו 6 או שי אה מינישטיר די גראנדי מובימינטו פאזירלי 7 אה קי שיג'א שיקו .אשי קומו ויאימוש אוש קי 8 אושאן מוייטו אנדאר אוש קאמיניוש אי אאוש

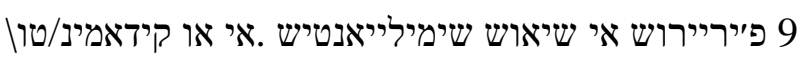
10 פ'אזי קריסיר מויטא אומידאדי אינו קורפו .אי פ'אזי 11 שיר בלאנקו .קומו ויאימוש אאוש אושוש .אה

53 Não obstante se trate do fonema /g/, gimmel é acompanhado pelo diacrítico que geralmente indica os fonemas $/ \mathrm{S} / \mathrm{ou} / 3 /$. 
12 קואנטא אי או דורמיר אי או ב’ילאר .אי קאדא אואה 13 דישטש דימודא אה קונפלישון קואנדו שון פ'ייטש 14 קומו נון קונב'יני .אה קינטא אי או פ'אזאמינטו 15 אי או אינג׳ימינטי .אי אישטש דואש דימודאן אה 16 קונפלישון אשיקידאד או אאומידאד .קואנדו נון 17 שון פ'ייטש קומו דיבין .אשי קומו או באניו מויטו

18 אמיאודו פ’אזי אל אומי פ'ריאו אי אומידו .אי 19 אשי גאזיר אומי מויטו קון מולייר .קי פאזי איל 20 אומי פ'ריאו אי שיקו. אה שישינא אי אוש אקסי 21 דינטיש דא אלמא .אשי קומו או קוידאדו אי אה

22 שאניא אי אומידו אי שיאוש שימיליאנטיש אי 23 אישטוש אוטרוש .דימודאן אה קונפלישון קואנ/דו| 24 מויטו אטוראן. מאש אש קואושש קונטרא נטורא

1 דימוראן מויטו אה קונפלישון אשי קומו שי קריסירי 2 נו קורפו מויטא פלימא פור פלאקיזא קי אלגונו דוש 3 מימרוש .או פור פ'אלימינטו די אלגואה דש וירטודיש

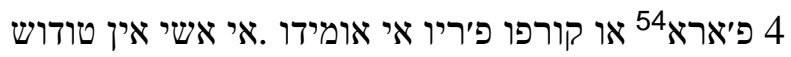
5 שיאוש שימיליאנטיש .מאיש אה מניירא די ג'ורגאר 6 אש קונפלישיואיש שיגונדו טודאש אישטש ראזוניש 7 שון אשי .ווש דיוידיש קטאר אש שינאאיש פרופיאש 8 קי איראן אנטי דו דימובימינטו .אשי קומו שי שון א/ש 9 ויאש אנג'ש או נון. אי אשי שי טיינין מויטוש קבילו/שו 10 אואו נון .או אוטרוש אוש קושטומיש .אי פור 11 אישטא קרירא אינטינדירידיש או דימודאמינטו 12 > > > שקי שי אקאבאן אוש קונפלישיואיש: 13 קאפיטולו פרימיירו קי פ'אלא נו פרולגו 14 דו ליברו > > דישי מאישטרי 15 שמואל אישפיריל פיישיקו די קורדובא 16 דיפויש דו אדיאנטאר או לוייבור די דיאוש לוייבאמינ/טול 17 שין פין אי שין פירפיקאסיון .נושא אינטיסיון אי

\footnotetext{
$54 P e$ é transcrito com o diacrítico que geralmente se usa para indicar o fonema /f/.
} 
18אינישטי ליברו טראקטאר די ריגלאש סירוג'יקאליש 19 אש קואאיש ריגראש נוש דישפוג'אמוש דוש ליברוש

20 דא פישיקא אש קואאיש קונפילארון אוש שאביוש

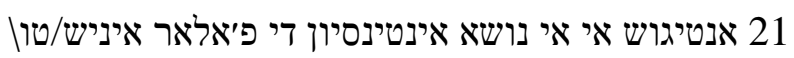
> > > > > > > > >

[f. 8r.]

1 ליברו בריבי מינטי גוארדאנדו קי מינגואה אין קואשן55 2 נושא פ'ורסא אלקאנסארי ניניואה דאש ריגראש קי שון 3 מיאישטיר אאקילאש קואושש קי נוש אקי פ'אלארי 4מוש שיגינדו או רוגו די אקיליש קי נוש רוגארון קילי/שו קיושיר

5 קונפילאשימוש אישטי ליברו .אי פושימוש לי 6 נומי או ניסישאריו אינא סירוג׳יאה פור קי שי 7 קונטינין אינילאוש ריגראש דאש סירוג׳יאה טיאוריק/א| 8 אי פראטיקא :אש קואאיש שון ניסישאריאש אטו/דו| 9 אומין קי קירא אושאר די סילורג׳יאה ג'אמאנדושי 10 סילורג'יאנו .אישטו דיגו פורקי אלגואוש שי אינטרי

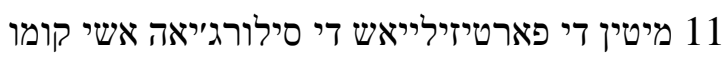
12 אלגואוש קי שי אטרימיטין די שאאר אש קיבראנטאדורש| 13 אי אש דישליגאדוראש .אינטון נון לוש שירא ניסי 14 שאריו טודו או קי שי קונטיני אינישטי ליברו .מאיש 15 שירלישאה ניסישאריו אקילייא פארטיזילייא די קי 16 איליש שי אינטרימיטין אי אה דידישיון דישטי ליב/רו| 17 אי קי או פרטימוש אה סינקו אוניבירשילידאדיש: 18 אה פרימיירא אינאש ריגראש אוניבירשאאיש 19 20 אינאש ריגראש פרטיקולאריש דאש שואות שות 21 ג'אגש נובש אי וילייאש אי אש פ'ישטולאש: 22 אה טירסיירא אין אש ריגראש דאש קיבראנטא 23 24 קוארטא אין אש ריגראש דש דישליגאדורש 25 > >דש קונג'ונטורש:

55 Acredito que waw antes de alef seja um erro de transcrição. 
[f. 8v.]

1אה קינטא אין אש ריגראש דש אפושטימאש

2

3 קומינסארימוש אפ'אלאר אינא פרימיירא אוניביר

4 שילידאדי .דישי אש אוטראש שיגינטי אורדינאדא

5 מינאי אי אין קומינסו די קאדא אוניבירשילידאדי

6 פורנימוש אש רובריקאש די שיאוש קפיטולוש: 


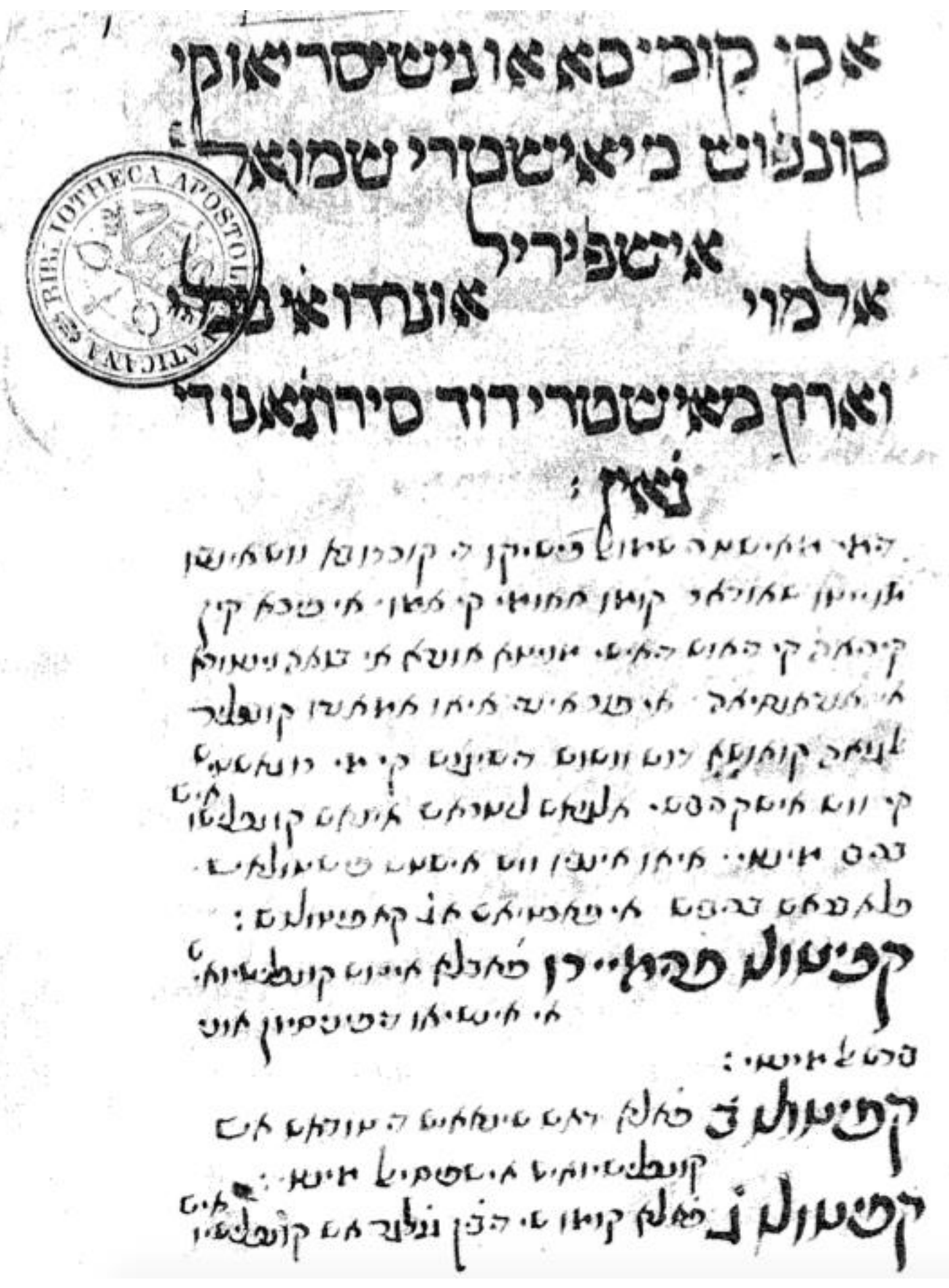

Ms. Vat. ebr. 372, f. 1r. 
[f. 1r.] Aqui começa o Neseçario $\left.\right|^{2}$ que conpus mestre Samuel $\left.\right|^{3}$ Esperel $\left.\right|^{4}$ al mui honrado e noble $\left.\right|^{5}$ varon mestre David cirujano de $\left.\right|^{6}$ Jaen: $\left.\right|^{7}$ De mi mestre Samuel fisico de Cordoba a vos envio $\left.\right|^{8}$ muito saudar como home que amo. e pera quen $\left.\right|^{9}$ queria que Deus dies[s]e muita honra e boa ventura $\left.\right|^{10} \mathrm{e}$ abundancia e pora ende eu amando cunplir $\left.\right|^{11}$ algua cousa dos vos[s]os desejos que me rogastes $\left.\right|^{12}$ que vos escreves[s]e alguas letras enas conplesoes $\left.\right|^{13}$ breve mente. Eu envio vos estas [e]pistulas $\left.\right|^{14}$ palavras breves e parti[d]as a tres capitulos: $\left.\right|^{15}$ Capitulo primeiro fabla enos conplesioes $\mid{ }^{16}$ e ensio definicion uni $\mid{ }^{17}$ versalmente: $\mid{ }^{18}$ Capitulo segundo fala das sinaais de todas as $\left.\right|^{19}$ conplesioes especial mente: $\left.\right|^{20}$ Capitulo terceiro fala como se deven julgar as conplesioes [f. 1v. $]^{1}$ e quaais son as cousas que deve home catar. $\left.\right|^{2}$ quando hovere de jurgar a conpleson e agora $\beta^{3}$ començare a dizer con ajuda de Deus meu Senhor:

${ }^{4}$ Capitulo primeiro que fala universal $\left.\right|^{5}$ mente ena conpleson e ensio $\left.\right|^{6}$ definicion: Dis[s]o Ibn Cina a conpleçon é qualidade $\Gamma^{7}$ que contece por fazimento de $\left.\right|^{8}$ qualidades contrairas achadas enos elementos mui $\left.\right|^{9}$ pequenas as partes porque se meçclen melhor as $\left.\right|^{10}$ unas con as oitras: Quer dizer que todas as $\left.\right|^{11}$ coisas deste mundo humano son conpostas de $\left.\right|^{12}$ quatro elementos que son fogo e ar e agua e ter[r]a. $\left.\right|^{13}$ desta maneira que con seus movimentos fazen os $\left.\right|^{14}$ unos enos oitros. E fazen donde os corpos $\left.\right|^{15}$ e a qualidade que vemos que vence mais que as $\left.\right|^{16}$ oitras chamamos aaquele corpo por aquela qualidade $\left.\right|^{17}$ e non nomeamos as outras qualidades $\left.\right|^{18}$ e por esto dis[s]e Ibn Cina calidade que contece: $\mid{ }^{19}$ e estas calidades se parten a duas partes en $\left.\right|^{20}$ todos os corpos universal mente que en alguos $\left.\right|^{21}$ é potencial e en alguos é actual. mais $\left.\right|^{22}$ os corpos en que é potencial son como as [f. 2r. $]^{1}$ as $\operatorname{prantas}^{56}$ e as menioras. e nos non queremos $\left.\right|^{2}$ falar do potencial. mas os corpos é actual $\left.\right|^{\beta}$ non as animalias. e noustra intencion é de falar $\left.\right|^{4}$ en el homen propria mente. e as conplesoes. $\left.\right|^{5}$ segundo as partiu Galeno son nove a ua $\left.\right|^{6}$ igual e as oito non iguais. mais o igual $\left.\right|^{7}$ dizen de muitas maneiras que aaoras o dizen a una $\left.\right|^{8}$ cousa a respecto de otra asi como dizen que $\left.\right|^{9}$ es igual ao homen a respecto de todas as $\mid{ }^{10}$ oitras cousas. ${ }^{57} \mathrm{e}$ aaoras dizen: $\mid{ }^{11}$ Igual a respecto de sua especie. asi como dize $\left.\right|^{12}$ igual a este leon a respecto de todos os leones $\left.\right|^{13}$ a este homen segundo todos os homees. e $\left.\right|^{14}$ esta é nos[s]a intencion do igual. e aaoras $\left.\right|^{15}$ lo dizen este igual aao conposto das quatro calidades $\mid{ }^{16}$ que non poge nenhua delas sobre a oitra e $\mid{ }^{17}$ esto segundo os filosofos non pode seer. $\left.\right|^{18}$ mais as oito non iguais as quatro son sinples $\left.\right|^{19}$ e as quatro conpostas. mas as sinples

\footnotetext{
${ }^{56}$ Prantas ] MS plantas prantas.

${ }^{57}$ Oitras ] MS animalia oitras.
} 
$\mathrm{I}^{20}$ son asi quando acharmos en un homen que $\left.\right|^{21}$ parecen en el sinaais de queentura mais e $\left.\right|^{22}$ acharmos a sequedade con a umidade igual $\left.\right|^{23}$ mente diremos aaquel corpo queente. sinplemente $\left.\right|^{24}$ e asi faremos en casa ua das oitras [f. 2v.] $\left.\right|^{1}$ tres qualidades. mas as quatro conpostas son $\left.\right|^{2}$ asi como quando acharmos sinaais de dos quali $\left.\right|^{3}$ dades que vencen e son: queente e seco queente e $\left.\right|^{4}$ umido. frio e seco. frio e umido. e non se pode $\left.\right|^{5}$ conpoer dos quatro elementos mas destos $\left.\right|^{6}$ que contamos ca sera igual e non igual. e é asi $\left.\right|^{7}$ como contamos. e queremos aqui fazer ua $\left.\right|^{8}$ figura por que se entenda mais esta maneira $\left.\right|^{9}$ como é o sinples e o conposto. e qual se conpon $\left.\right|^{10}$ con qual é qual non. e esta é a figura $\left.{ }^{58}\right|^{11}$ e por $\left.\right|^{12}$ que nos[s]a $\left.\right|^{13}$ intencion $\mid{ }^{14}$ é de falar $\mid{ }^{15}$ breve mente. $\mid{ }^{16}$ Queremos aqui $\mid{ }^{17}$ acabar este $\mid{ }^{18}$ primeiro capitulo $\left.\right|^{19}$ e falar $\left.\right|^{20}$ eno segundo:

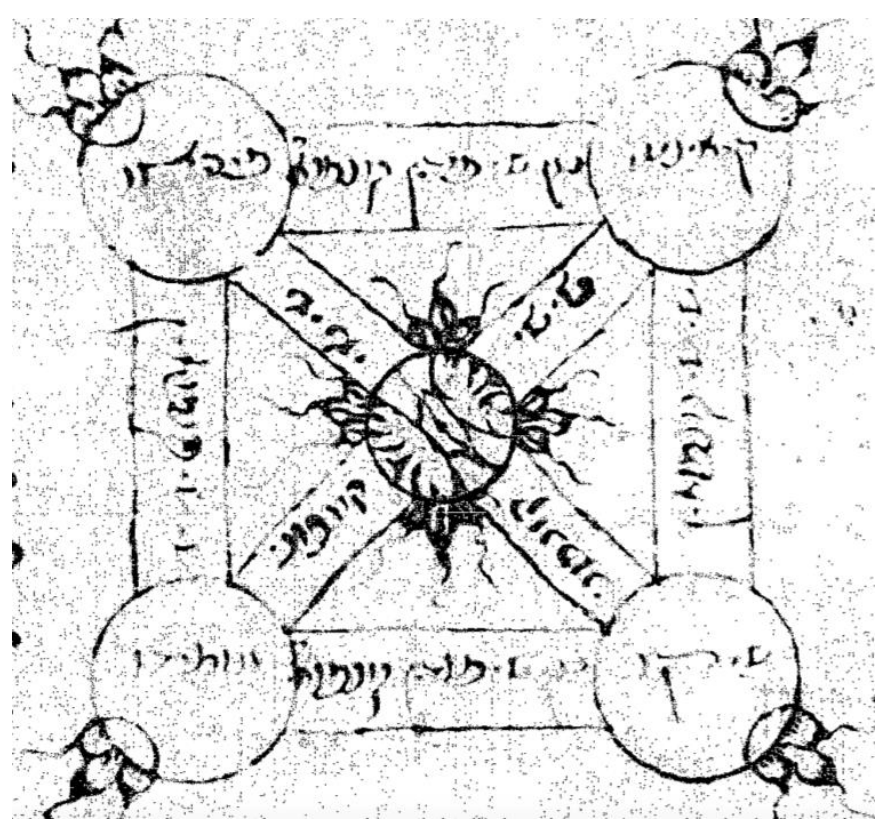

${ }^{21}$ Capitulo segundo fala das sinaais de $\left.\right|^{22}$ todas as $\left.\right|^{23}$ conplesoes: As sinaais de todas as conplesoes se parten [f. 3r. $]^{1}$ se parten en quatro par[tes] ${ }^{59}$ as uas se toman dos $\left.\right|^{2}$ nembros do sentido e as oitras da virtude $\left.\right|^{3}$ vidal e as oitras se toman dos memros $\left.\right|^{4}$ do governo e as oitras toman dos nembros da $\left.\right|^{5}$ engendraçon. e eu por razon de abreviar e $\left.\right|^{6}$ e porque seja mas achegados ao seso do que $\left.\right|^{7}$ o quiser aprender. porne aligada mente as $\left.\right|^{8}$ sinaais de todos estos

\footnotetext{
${ }^{58}$ Nesta figura aparecem as palavras (da direita para a esquerda) queente, frio; seco; umido. Nas faixas diagonais e verticais aparece a frase si se conpon, remetendo às possíveis combinações de quente-úmido, quente seco, frioúmido e frio-seco; nas faixas horizontais se lê non se poden conpor.

${ }^{59}$ Texto danificado, suponho que se trate de partes.
} 
memros a cada $\left.\right|^{9}$ ua das conpresioes. e començar das $\left.\right|^{10}$ sinples e depois iria. aas conpostas. E $\left.\right|^{11}$ esto é segundo orden. digo que se for queente $\left.\right|^{12}$ sera de sentido sutil e agudo e apres[s]oroso $\left.\right|^{13}$ e se o falar en todas suas cosas e en $\left.\right|^{14}$ todos seus movimentos. e a virtude vidal $\left.\right|^{15}$ é nele forte. que sera sanhoso e atrevido $\left.\right|^{16}$ e baralhador. e non medroso e as virtudes do $\left.\right|^{17}$ governo fortes é nele, asi como haber savor $\left.\right|^{18}$ de comer ben e cozer ben a vianda e haver mais $\left.\right|^{19}$ carne que non gros[s]ura nen sebo. e muitos cabelos $\left.\right|^{20}$ por todo o corpo e vermelho o coor de sua $\left.\right|^{21}$ cara e a virtude da geeraçon é nele forte $\left.\right|^{22}$ e se fore frio seus sinaais son contrairas $\left.\right|^{23}$ aas do queente asi como do seu torpe e non $\left.\right|^{24}$ sutil nen agudo e vagaroso en todas suas [f. $3 \mathrm{v}$. $]^{1}$ cousas tan ben en fal $[\ldots]^{60}$ enos oitr[os] $\left.\right|^{2}$ movimentos. e a virtude [vi]dal é nele flaca: $\left.\right|^{3}$ Tarde sanhoso o nunca manso en todas suas $\left.\right|^{4}$ maneiras. e medroso. e as virtudes do governo $\left.\right|^{5}$ flacas en ele non haber sabor ben de comer. $\left.\right|^{6}$ nen de cozer ben a vianda. e haber mais sebo que carnes. $\left.\right|^{7} \mathrm{e}$ os cabelos de seu corpo ao que sejan poucos $\left.\right|^{8}$ e se foren que sejan blancos. o que teren a blancos $\mid{ }^{9}$ e lizanhos delgados e flacos. o qual ${ }^{61}$ se le $\mid{ }^{10}$ volvere a esta conplesion umidade. e a $\left.\right|^{11}$ virtude da engendraçon é nele flaca e quando $\left.\right|^{12}$ fore umido sera torpe mui olvidado. mui dormedor $\left.\right|^{13}$ e non esperto pera as cousas e a $\left.\right|^{14}$ virtude vidal desta maneira o pulso brando $\left.\right|^{15}$ e ele achegue a ensanharse e achegue a tornarse $\mid{ }^{16} \mathrm{e}$ ainda sera medroso e a virtude governante $\left.\right|^{17}$ sera enele desta maneira as veas de todo seu $\left.\right|^{18}$ corpo seran blandas e tera muita carne e muito $\left.\right|^{19}$ sebo e todo seu corpo blando e que sobran $\left.\right|^{20}$ e nel muitas umidades. e o cabelo dele blando $\left.\right|^{21}$ e a virtude da enjendraçon é nele flaca. e $\left.\right|^{22}$ de mais se volvere quale.friura ca será en el $\left.\right|^{23}$ esperma mui diluada corente. e se fore seco $\left.\right|^{24}$ seus sinaais son contrarias a estas do $\mid$ umido [f. 4 r.] $\left.\right|^{1}$ umido, asi como acordarse ben aas cousas. $\left.\right|^{2}$ e non seer dormedor e seer esperto per las $\left.\right|^{3}$ cousas. e as oitras virtudes é nele contrarias. $\left.\right|^{4}$ aas do umido por esta maneira. $\left.\right|^{5}$ agora habemos dito as sinaais das quatro $\left.\right|^{6}$ conplesoes sinples. mais as quatro conpostas $\left.\right|^{7}$ entendense das sinples. mais por razon que $\left.\right|^{8}$ se entenda melhor direi algua cousa breve $\left.\right|^{9}$ mente. se o corpo fore queente e umido $\left.\right|^{10}$ seus sinaais son estas: sera de bon seso $\left.\right|^{11}$ e de muito dormir entre meaao entre vagaroso $\left.\right|^{12}$ ou apres[s]oroso e de muitos sonos e a virtude $\left.\right|^{13}$ vidal é nele comunal. agonia sanhoso o agonia $\left.\right|^{14}$ afagado e seu pulso grande e blando $\left.\right|^{15}$ virtude governante é nele forte a sabor ben de $\mid{ }^{16}$ comer. e coze bem a vianda e habra muitas $\mid{ }^{17}$ carnes e muito sebo todo seu corpo queente $\mid{ }^{18}$ brando. anchas as veas e brandas e os $\mid{ }^{19}$ cabelos do seu corpo seran muitos e brandos $\left.\right|^{20}$ e a virtude da enjendraçon sera forte se non $\left.\right|^{21}$ que é cor[r]ente sua esperma, e as sinaais $\left.\right|^{22}$ do frio seco son contrarias destas $\left.\right|^{23}$ ditas. mais as sinaais do quente e seco $\left.\right|^{24}$ e as

\footnotetext{
${ }^{60}$ Texto ilegível.

${ }^{61} \mathrm{O}$ o qual ] MS alcunos o qual. A palavra apagada é pouco legível, como também sua reescritura. 
sinaais do frio e umido por esta [f. 4v.] $\left.\right|^{1}$ crera que mostramos. tomar das sinples $\left.[\ldots]^{62}\right|^{2}$ conponeras. mais as sinaais do tenprado $\left.\right|^{3}$ que é o igual son quando as sinaais dos $\left.\sin \right|^{4}$ nples on pojan as umas sobre as oitras. $\left.\right|^{5}$ e faze todas as obras naturaais cunprida $\left.\right|^{6}$ mente. en o melhor que pos[s]a seer ena espe $\left.\right|^{7}$ cie do homen. e agora habemos dito as sinaais $\left.\right|^{8}$ das conplesoes breve mente. e agora diremos $\left.\right|^{9}$ como se deben jurgar estas conplesoes:

${ }^{10}$ Capitulo terceiro como é a maneira $\mid{ }^{11}$ de jurgar a conpleson $\left.\right|^{12}$ e que son as cousas que debe homen de catar quando $\left.\right|^{13}$ quiser jurgar. a maneira de jurgar a conpleson $\left.\right|^{14}$ debe seer esta. debemos tomar todas as $\left.\right|^{15}$ sinaais da conpleson tenprada e majinaras $\left.\right|^{16}$ ante os olhos. e veer aqual qualidade se $\left.\right|^{17}$ encolgan as sinaais e asi jurgaremos. e $\left.\right|^{18}$ se vermos que parecen aquelas sinaais que se $\left.\right|^{19}$ inclinan a algua qualidade forte mente jul $\left.\right|^{20}$ garemos que é muito saido da igualdade. e $\left.\right|^{21}$ se foren flacas as sinaais jurgaremos que é $\left.\right|^{22}$ pouco saido da igualdade. e debemos catar $\left.\right|^{23}$ quando quisermos julgar esta encliçon en tres $\left.\right|^{24}$ cousas. a primeira as cousas naturaais e a $\mid$ segunda [f. 5r. $]^{1}$ segunda as cousas non naturaais. a terceira as cousas $\left.\right|^{2}$ fora de natura. que cada cousa destas demuda $\left.\right|^{3}$ a conpleson ca as cousas demudan a conple $\left.\right|^{4}$ son por quatro maneiras. a primeira segundo desvariamento $\left.\right|^{5}$ dos memros. a segunda segundo as idades. a terceira $\left.\right|^{6}$ segundo as $\mathrm{e}^{63}$ climas. a quarta segundo o macho e a $\left.\right|^{7}$ femea. e convene que falemos algun pouco enes $\left.\right|^{8}$ tas cousas. o desvariamento dos nemros é $\left.\right|^{9}$ en duas maneiras. ca el primeiro é igual e o otro $\left.\right|^{10}$ non igual. e o igual desvariamento e aquel que $\left.\right|^{11}$ son seus memros segundo deben ser os queentes $\left.\right|^{12}$ queentes e asi ou outros e el non igual $\left.\right|^{13}$ desvariamento e aquel que son seus memros $\left.\right|^{14}$ contrario do que deben a seer. asi como os que han $\left.\right|^{15}$ de seer queentes que sejan frios. e agora diremos $\left.\right|^{16}$ do igual desvariamento queson enos memros $\left.\right|^{17}$ e depois vos entenderedes o non igual con as $\left.\right|^{18}$ sinaais que dis[s]emos de suso. digo que o mais $\left.\right|^{19}$ queente que é enel corpo del homen é esprito $\left.\right|^{20}$ vidal. e depois o coraçon que é sua morada $\left.\right|^{21}$ do esprito vidal. e començamento da calor $\left.\right|^{22}$ natural e depois a sangre. e depois o figado $\left.\right|^{23}$ e depois a carne. e depois o musclo. e $\left.\right|^{24}$ depois o baço. e depois os rinioes e depois [f. 5v. $]^{1}$ as peles das arterias. e depois as peles das $\left.\right|^{2}$ veas. e depois o coiro o de todo o corpo $\left.\right|^{3}$ que é tenperado. e o mais tenperado é igual $\left.\right|^{4}$ e o coiro da palma: E os memros frios $\left.\right|^{5}$ son asi. e mais frio que é eno corpo son os $\left.\right|^{6}$ cabelos. e depois o os[s]o. e depois a ternilha. $\left.\right|^{7} \mathrm{e}$ depois as pelejuelas. e depois os nervios $\left.\right|^{8}$ depois a nuca. depois o miolo. depois o sebo. $\left.\right|^{9}$ depois o coiro: $E$ os memros umidos $\left.\right|^{10}$ son estes. a cosa mais umida que e eno $\left.\right|^{11}$ corpo é a frema. depois a sangre. depois $\left.\right|^{12}$ a gros[s]ura. e depois o sebo. e depois o $\left.\right|^{13}$ miolo. depois a

\footnotetext{
${ }^{62}$ Texto ilegível.

${ }^{63}$ Alef-yod são acrescentados ao lado das letras precedentes alef-shin. 
nuca. depois a carne das $\left.\right|^{14}$ tetas e dos genitorios. depois o pulmon. de $\mid{ }^{15}$ pois os rinioes. depois os musclos. depois $\left.\right|^{16}$ o coiro. e os membros mais secos do corpo $\left.\right|^{17}$ son os cabelos e depois o os[s]o. e depois $\left.\right|^{18}$ a ternilha. e depois os atadores. depois $\left.\right|^{19}$ as cordas. depois as arterias depois as $\left.\right|^{20}$ veas. depois os nervios do movimento. depois $\left.\right|^{21}$ o coraçon. depois os nervios do sentido. depois $\left.\right|^{22}$ o coiro. e agora habemos dito a conpleson $\left.\right|^{23}$ de cada memro sinplez mentre ${ }^{64}$ e vos non $\left.\right|^{24}$ habredes grave de conpoer alo enxenplo ${ }^{65}$ desto o $\mid$ coraçon [f. 6r.] $]^{1}$ coraçon. (depois o nervio do sentido depois o coiro). $\left.{ }^{66}\right|^{2}$ (e agora habemos dito a conpleson de cada) $\left.\right|^{3}$ (membro sinple mentre). e mais queente que todos $\left.\right|^{4}$ os otros memros. e que ha asi seus nem $\left.\right|^{5}$ bros é igual conposto. e quem desvaria disto $\left.\right|^{6}$ a mais o meos non e igual conposto. e $\left.\right|^{7}$ a maneira do julgar enesta razon e asi que $\left.\right|^{8}$ quando oirdes o miolo e frio quer dizer que $\left.\right|^{9}$ e mais frio que non deve de seer e quando $\left.\right|^{10}$ oirdes o miolo e queente ${ }^{67}$ quer dizer $\left.{ }^{68}\right|^{11}$ queente ${ }^{69}$ que non deve de seer e asi en todos os $\left.{ }^{70}\right|^{12}$ otros memros. A segunda maneira das cousas naturaais $\left.\right|^{13}$ que demudan a conpleson son as edades $\left.\right|^{14} \mathrm{e}$ as idades son quatro a primeira e $\left.\right|^{15}$ desde que nace fasta catorce anos e queente e umido $\left.\right|^{16}$ a segunda e fasta trinta o trinta e cinco anos. e e queente e $\left.\right|^{17}$ seco a terceira e fasta ses[s]enta anos e e frio e seco. $\left.\right|^{18}$ a quarta e fasta a morte. e e segundo natura $\left.\right|^{19}$ mais frio e mais seco que terceira ${ }^{71}$ idade $\left.\right|^{20}$ mais por razon que $\mathrm{se}^{72}$ engendran enele muitas $\left.\right|^{21}$ seporfolidades julgan que e mais frio e umidade $\left.\right|^{22}$ a terceira maneira das cosas naturaais que demudan $\left.\right|^{23}$ as conplesoes que e segundo as aclimas. $\left.\mathrm{E}\right|^{24}$ as climas son sete e os que moran ena linha [f. 6v.] $\left.\right|^{1}$ da igualdade que veino de oriente a ponente. e os $\left.\right|^{2}$ que moran cerca asi como os que moran ena clima $\left.\right|^{3}$ quatro. enestas conhecertan as sinaais das conplesoes $\left.\right|^{4}$ ditas: Mais os que moran alisados da linha da $\left.\right|^{5}$ igualdade aqual cabo queira. o que que ${ }^{73}$ seran mui blancos $\left.\right|^{6}$ ademas da grande frior. o que seran quemados negros $\Gamma^{7}$ da grande queenturaura. pois a maneira do julgar $\left.\right|^{8}$ e nesta razon e asi que aainda que vos vejades $\left.\right|^{9}$ aquel quemado negro e seus cabelos negros e cre $\mid{ }^{10}$ spos. sepades que e frio do conpleson. e asi $\mid{ }^{11}$ enos oitros mui blancos que son queentes $\left.\right|^{12}$ conpleson ainda que vos lavedes de cabelos lizanhos $\left.\right|^{13}$ e mui pocos. mais pera vos julgar direita $\mid{ }^{14}$ mente fragmentes qual e o tenprado en cada $\left.\right|^{15}$ clima. e

\footnotetext{
${ }^{64}$ Sinplez mentre ] MS sinplez mentr mentre.

65 Transcrevo shin mais diacrítico com o grafema latino " $\mathrm{x}$ ".

${ }^{66}$ Parênteses no texto.

${ }^{67}$ E queente ] MS e frio queente.

68 Dizer ] MS dizer que mais.

69 queente ] MS frio queente.

${ }^{70}$ No fim da linha 11, aparece uma nota que provavelmente foi inserida só depois: e tan frio como (פריו טאן אי קומו).

${ }^{71} \mathrm{~A}$ palavra é escrita com tzade (tertzeira).

72 se ] as se.

${ }^{73}$ Repetição no texto.
} 
da quel entenderedes todos los de sua $\mid{ }^{16}$ clima. a quarta maneira das cousas naturaais $\mid{ }^{17}$ que demudan a conpleson e o macho e a femea $\mid{ }^{18}$ e esta maneira que a femea e mais fria $\mid{ }^{19}$ e mais umida que o macho pois a maneira $\left.\right|^{20}$ do julgar e nesta razon que vos maginedes a $\left.\right|^{21}$ mais achegada igualdade entre todas as $\left.\right|^{22}$ mulheres. e de aquela tomar entendim[ento] pera $\left.\right|^{23}$ as otras todas e agora habemos acabado $\left.\right|^{24}$ as cosas naturaais que demudan a conpleson | mais [f. 7r. $]^{1}$ mais as cousas non naturaais son seis e son o aire $\left.\right|^{2}$ que nos cerca o sera queente o frio. a segunda $\left.\right|^{3}$ o comer e o bever que nos fara gordos ou delgados $\left.\right|^{4}$ o frios o queentes. e a terceira o movime $\left.\right|^{5}$ nto e quedamento que o movimento se e muito $\left.\right|^{6}$ o se a minister de grande movimento fazer-le $\left.\right|^{7}$ a que seja seco. asi como viemos os que $\left.\right|^{8}$ usan muito andar os caminhos e aos $\left.\right|^{9}$ fereiros e seus semelhantes. e o quebramento $\mid{ }^{10}$ faze crescer muita umidade eno corpo. e faze $\left.\right|^{11}$ ser blanco. como viemos aaos osos. A $\left.\right|^{12}$ quarta e o dormir e o velar e cada ua $\left.\right|^{13}$ destas demuda a conpleson quando son feitas $\left.\right|^{14}$ como non convene. a quente e o vazamento $\mid{ }^{15}$ e o enchimento e estas duas demudan a $\mid{ }^{16}$ conpleson a sequedad e a umidad. quando non $\left.\right|^{17}$ son feitas como deben. asi como o banho muito $\left.\right|^{18}$ umido faze al home frio e umido. e $\left.\right|^{19}$ asi jazer home muito con mulher que faz el $\left.\right|^{20}$ home frio e seco. a sesena os acçi $\left.\right|^{21}$ dentes da alma. asi como o cuidado e a $\left.\right|^{22}$ sanha é umido e seus semelhantes e $\left.\right|^{23}$ estos otros demudan a conpleson quando $\left.\right|^{24}$ muito aturan. mas as cousas contra natura [f. $\left.7 \mathrm{v}.\right]^{1}$ demudan muito a conpleson asi como se crescere $\left.\right|^{2}$ no corpo muita flema por flaqueza de alguno dos $\left.\right|^{3}$ memros. o por falimento de algũa das virtudes $\left.\right|^{4}$ para o corpo frio e umido. e asi en todos $\left.\right|^{5}$ seus semelhantes. mais a maneira de jurgar $\left.\right|^{6}$ as conplesioes segundo todas estas razones $\Gamma^{7}$ son asi. vos devedes catar as sinaais propias $\left.\right|^{8}$ que eran ante do demovimento asi como se son as $\left.\right|^{9}$ veas anchas ou non. e asi si e tienen muitos cabelos $\left.\right|^{10}$ ou non. e otros os costumes e por $\left.\right|^{11}$ esta crera entenderedes o demudamento $\left.\right|^{12}$ aqui se acaban os conplesoes: $\left.\right|^{13}$ Capitulo primeiro que fala no prol[o]go $\left.\right|^{14}$ do livro des[s]e mestre $\left.\right|^{15}$ Samuel Esperel fisico de Cordoba $\left.\right|^{16}$ depois do adiantar o loivor de Deus loivamento $\left.\right|^{17}$ sen fin e sen perpicacion nos[s]a intencion é $\left.\right|^{18}$ eneste livro tractar de reglas cirujicales $\left.\right|^{19}$ as quais regras nos despojamos dos livros $\left.\right|^{20}$ da fisica as quaais conpilaron os sabios $\left.{ }^{74}\right|^{21}$ antigos e é nos[s]a intencion de falar enes $\mid$ to livro [f. 8r.] $\left.\right|^{1}$ livro brevemente guardando que mengua en caso $\left.\right|^{2}$ nos[s]a força alcançare nenhua das regras que son $\left.\right|^{3}$ meester a aquelas cousas que nos aqui falare $\left.\right|^{4}$ mos segundo o rogo de aqueles que nos rogaron queles $\left.\right|^{5}$ conpilas[s]emos este livro pusemos-le $\left.\right|^{6}$ nome o Necesario $^{75}$ ena cirugia porque se $\left.\right|^{7}$ contenen enelaos regras da cirugia teorica $\left.\right|^{8}$ e pratica: as quaais son necesarias a

\footnotetext{
${ }^{74}$ Os \sabios/ ] MS os livros \sabios/.

${ }^{75}$ Se lê Necesario, que difere de neseçario, forma presente no título.
} 
todo $\left.\right|^{9}$ homen que quera usar de cilurgia chamandose $\left.\right|^{10}$ cilurjano. esto digo porque alguos se entre $\left.\right|^{11}$ meten de partezilhas de cilurgia asi como $\left.\right|^{12}$ alguos que se e[n]tremeten de saar as quebrantaduras $\left.\right|^{13}$ e as desligaduras. enton non les sera nece $\left.\right|^{14}$ sario todo o que se contene eneste livro mais $\left.\right|^{15}$ ser-lesa necesario aquelha partezilha de que $\left.\right|^{16}$ eles se entremeten e a dedision deste livro $\left.\right|^{17}$ e que o partimos a cinco universelidades: $\left.\right|^{18}$ A primeira enas regras universaais $\left.\right|^{19}$ das chagas. A segunda $\left.\right|^{20}$ enas regras particulares das $\left.\right|^{21}$ chagas novas e velhas e as fistulas. $\left.\right|^{22}$ A terceira enas regras das quebrantaduras $\left.\right|^{23}$ dos os[s]os. A $\left.\right|^{24}$ quarta enas regras das desligaduras $\left.\right|^{25}$ das conjunturas. [f. 8v.] ${ }^{1}$ A quinta enas regras das apostemas $\left.\right|^{2}$ por maneira universal e agora $\beta^{3}$ començaremos a falar ena primeira univer $\left.\right|^{4}$ selidade. des[s]e as otras seguinte ordenada $\left.\right|^{5}$ mente e en començo de cada universalidade $\left.\right|^{6}$ fornemos as rubricas de seus capitulos.

\section{Bibliografia}

Ms. Vat. ebr. 372 - Biblioteca Apostolica Vaticana

Ms. Vat Lat. 13196, ff. 301r.-v., Index librorum omnium Hebraicorum, tam impressorum quam Mss., qui anno Jubilei MDCL in B(iblioteca) V(aticana) extabant, Giulio Bartolocci.

BEPJ Biblioteca española-portugueza-judaica. Dictionnaire bibliographique des auteurs juifs de leurs ouvrages espegnoles et portugais et des cuvres sur et contre les juifs et le Judaïsme, M. Kayserling (ed.), Strasbourg: Charles J. Trubner, 1890.

BH Bibliotheca Hebrae, sive notitia tum auctorum Hebr. cuiuscumque aetatis tum scriptorum que vel Hebraica primum exarata vel ab aliis conversa sunt ad nostram atatem deducta, J. C. Wolf (ed.) Hamburgi \& Lipsiæ: impensis Christiani Liebezeit, 1715.

ALVERNY, Marie-Thérèse d'. Les traductions à deux interprètes : d'arabe en langue vernaculaire et de langue vernaculaire en latin. Traduction et traducteurs au Moyen Âge, Actes du colloque international du CNRS organisé à Paris, Institut de recherche et d'histoire des textes les 26-28 mai 1986, Aubervilliers: Institut de Recherche et d'Histoire des Textes (IRHT), 1989, pp. 193-206.

ASLANOV, Cyril. Sociolingüística histórica de las lenguas judías. Buenos Aires: Lilmod, 2011. 
Latin in Hebrew Letters: The transliteration/Transcription/Translation of a Compendium of Arnaldus de Vila Nova's Speculum medicinae, in: R. Fontaine \& G. Freudenthal (ed.), Latin-into-Hebrew: Texts and Studies, (Volume One: Studies), Leiden-Boston: Brill, 2013a, pp. 45-58.

From Latin Into Hebrew Through the Romance Vernaculars: The Creation of and Interlanguage Written in Hebrew Characters, in: R. Fontaine \& G. Freudenthal (ed.), Latininto-Hebrew: Texts and Studies, (Volume One: Studies), Leiden-Boston: Brill, 2013b, pp. 6984.

ASSEMANI, S. E., ASSEMANI J. S. Biblioteca Apostolica Vaticance codicum manuscriptorum catalogus, I/1. Codices Ebraicos et Samaritanos complectens. Romæ: A. Rotilius in æd. Maximorum, 1756.

BLONDHEIM, David S. An Old Portuguese work on manuscript illumination, Jewish Quarterly Review, 19 (1928), pp. 97-135.

Additional Note on «An Old Portuguese Work on Manuscript Illumination, Jewish Quarterly Review, 20 (1930), pp. 283-84.

CANTORI, Valentina. Il Necessario di Samuel Esperel trascritto da Yosef Catelan: Edizione e commento linguistico del codice Vat. ebr. 372, 2017, pp. 360, Dipartimento di Studi UmanisticiDepartment of Romance and Latin American Studies, Universidade de Macerata - Universidade Hebraica de Jerusalém, Macerata - Jerusalém. [Tese de doutorado].

CASTRO, Ivo de. Notas sobre a língua do Livro de como se fazen as cores (ms. Parma 1959), in: L. U. Afonso (ed.) The Materials of the Image. As Materias da Imagem, Lisboa: Catedra de Estudos Sefarditas “Alberto Benveniste” da Universidade de Lisboa, 2010, pp. 87-96.

CASSUTO, Umberto. I manoscritti palatini ebraici della Biblioteca Apostolica Vaticana e la loro storia. Città del Vaticano: Biblioteca Apostolica Vaticana, 1935.

DUCHOWNY, Aléxia Teles. De magia (Ms. Laud Or. 282, Bodleian Library): edição e glossário, 2014, Arquivos do NEHiLP, Núcleo de apoio à pesquisa em Etimologia e História da Língua Portuguesa, FFLCH/USP, São Paulo.

HERRERA, María Teresa, VÁZQUEZ DE BENITO, María Concepción. Arabismos en el castellano de la medicina y farmacopea medievales. Apuntes para un nuevo diccionario (I), Cahiers de linguistique hispanique médiévale, 6 (1981), pp. 123-169.

Arabismos en el castellano de la medicina y farmacopea medievales. Apuntes para un nuevo diccionario (II), Cahiers de linguistique hispanique médiévale, 7 (1982), pp. 173- 216. 
HILTY, Gerold. El libro conplido de los iudizios de las estrellas. Madrid: Real Academia Española, 1954.

KOREN, Nathan. Jewish Physicians, A Biographical Index. Jerusalem: Israel Universities Press, 1973.

MATOS, Débora. The Ms. Parma 1959 in the Context of Portuguese Hebrew Illumination, 2011, pp. 220, Faculdade de Letras da Universidade de Lisboa, Lisboa. [Tese de mestrado].

PROVERBIO, Delio Vania. Una nuova versione ebraica del Lilium Medicinae, in Miscellanea Bibliothecae Apostolicae Vaticanae X. Città del Vaticano: Biblioteca Apostolica Vaticana, 2003, pp. 227-262.

RICHLER, Benjamin. Hebrew Manuscripts in the Vatican Library: Catalogue, Compiled by the Staff of the Institute of Microfilmed Hebrew manuscripts, Jewish National and University Library, Jerusalem; edited by Benjamin Richler; palaeographical and codicological descriptions Malachi Beit-Arié in collaboration with Nurit Pasternak. Città del Vaticano: Biblioteca Apostolica Vaticano, 2008.

ROTH, Norman. Daily Life of the Jews in the Middle Ages. Westport: Greenwood Press, 2003. SARTON, George. Introduction to the History of Science. Baltimore: The Williams \& Wilkins Company, 1948.

SOARES DE CARVALHO MENDES, Maria Adélia, Pedro Hispano. Tesoro de los proves. Versão em judeu-castelhano aljamiado (séc. XV), Medicevalia, Textos e Estudos, 15-16 (1999). STROLOVITCH, Devon L. Old Portuguese in Hebrew Script: Convention, Contact and Convivência, 2005, Cornell University, Ithaca (NY). [Tese de doutorado].

VISAN, Irina. Hebrew Medical Manuscripts in Portugal between the $13^{\text {th }}$ and the $16^{\text {th }}$ centuries, História, Revista da FLUP, 6 (2016), pp. 191-198. 